\title{
ORGANIZAÇÃo DE PARTIDOS
}

Para que se forme um partido é preciso que tenha idéas e programma e não queira substituir uma oligarchia por outtra, o que pouco interessará ao povo.

Os partidos são necessarios á vida do paiz, mas os da opposição não devem unicamente querer atacar o governo para derrubal-o e uma vez no poder fazerem precisamente o que elle fazia. Deve antes trabalhar para que seja uma realidade a democracia, o governo do povo pelo povo e para o povo, luctar indefessa e desinteressadamente pela felicidade do povo, educando-o e amparando-o contra as demasias do poder.

0 partido, principalmente o de opposição, se for honestó, seguirá o seguinte codigo: — " 1 - Prudencia; 2 — Constancia; 3 - Disciplina; 4 - Honradez; 5 - Doutrina; 6 - Tolerancia; 7 - Respeito aos direitos da maioria; 8 - Patriotismo; 9 - Esperança; 10 - Instruoção"

Mas será esse o programma dos partidos formados em nossa terra?

\section{FALTA DE EDUCAÇÃO DO POVO}

Fala-se muito em falta de educação do povo: procla. mam-na os do governo e os da opposição.

Mas o que fizeram em nossa patria politicos e intellectuaes para corrigir o mal?

Clamar contra elle e clamar ainda! Nada!

Doutores, bachareis, professores civis e miltares, padres, deputados, senadores, advogados, medicos, engenhei- 
ros, estudantes, ninguem, nenhuma classe, nenhuma associação procurou corrigir o mal.

Não se formou nenhum partido desinteressado para educar o povo, para ensinar-lhe a amar o Brasil e governar-se livremente..

Essa é a verdade!

\section{SITUAÇÃO DO POVO BRASILEIRO}

O nosso povo não conhece a nossa historia, é ignorante, não tem educação moral e civica, por culpa dos catôes burlescos e dos liberaes de fachada que nada fizeram por elle.

Ha no Brasil, ao lado de uma multidão de brasileiros que apodrecem de miseria, ao desamparo, uma enorme massa de extrangeiros não assimilados, que põe em perigo a nossa civilização e a nossa cultura: culpa dos plutocratas inconscientes e dos censores caricatos que nada fazem a não ser criticar os actos do governo sem se preoccuparem com o bem publico, reflectindo com o estomago, e não com o cerebro, sentindo com os intestinos e não com o orgão nobre - com o coração.

A situação do Brasil é triste, é preciso fazer alguma coisa para melhorar o estado actual.

E' preciso que os homens de bem, os verdadeiros patriotas, se unam para reerguer o Brasil, conservando-o intacto, forte, grande e respeitado.

\section{PROGRAMMA}

Proponho as seguintes idéas para um partido honesto e desinteressado ou para uma associação patriotica, que tenha em vista o bem publico:

$10^{\mathrm{a}}$ - Condemnar a revolução e todos os meios violentos. 
0 partido acceita como principio que os meios violentos podem significar um desafogo, uma erupção de colera ou de indignação, mas não são processos regulares de progresso.

$\mathrm{Na}$ lei encontra o povo meios de luctar contra qualquer despotismo, e exemplos frisantes dão a França sob Napoleão III e a Allemanha sob Guilherme I.

$2 .^{a}$ - Bater-se pela educação civica para ser alcançado o respeito á lei.

E' o respeito á lei por parte das autoridaldes, o mais seguro meio de evitar as explosões revolucionarias.

O outro remedio é a concessão dè certas franquezas que correspondem ao quel aspira o povo em um dado momento, o que é aspiração popular.

$3 .^{a}$ - Como processo para esclarecimento do governo, ha a imprensa e a tribuna, e portanto, deverá o partido ou a associação patriotica fazer quanto puder para que haja liberdade de manifestação do pensamento.

Não é só a liberdade de imprensa e de tribuna que é indispensavel em um governo democrätico, mas sim tambem e principalmente a de escolha dos representantes do póvo, e para isto é indispensavel o voto secreto, sem o qual é uma burla o regimen representativo.

$4 .^{2}$ - Luctar pela harmonia dos poderes e para que seja uma realidade o systema de equilibrios e contrapesos.

Todo o regimen em que qualquer dos poderes tem preponderancia sobre os outros longe de ser democratico é despotico.

$5 .^{a}$ - Tornar effectiva a responsabilidade dos funccionarios improbos. Para esse effeito medidas bastante complexas deveriam ser adoptadas, como, por exemplo, a correição no fôro, os processos rapidos na administração, para ser apurada a culpa dos empregados, a exoneração e a condemnação dos funccionarios em perdas e damnos, 
quando a Municipalidade, o Estado ou a União tivesse de indemnizar o particular por culpa do funccionario.

Numa palavra: procurar por leis ordinarias e por cumprimento exacto, restricto de taes leis, que seja uma realidade o excellente dispositivo do art. 82 da Constituição Federal, que tem sido até hoje letra morta

$6{ }^{a}$ - Pugnar pela unidade da patria.

Comquanto economicamente pareça que S. Paulo se sacrifica pelos demais Estados da União, uma vista de conjuncto sobre todas as necessidades de nossa terra, mostra que muitos serviços deve elle aos outros membros da federação.

Unidade de leis, troca de professores entre as Faculdades da União, remoção de funccionarios de uns para outros Estados, facilidade de communicação entre os diversos pontos do paiz, reducção de taxas de telegraphos e correios, facilitar-se a troca de productos entre todos os brasileiros, protecção no limite do possivel ao intercambio de productos nacionaes, etc., eis um programma a seguir para obtermos a manutenção da integridade nacional.

7. ${ }^{\mathrm{a}}$ - Manter a maior harmonia com as Republicas vizinhas.

Para isso, desenvolver com ellas o intercambio intellectual e economico (v. o interesse economico em relações internacionaes. Revista da Faculdade de 1913, v. XXI).

8. ${ }^{a}$ - Ainda como complemento, são ídéas a meditar: a) acabar com o funccionalismo vitalicio; b) unidade de processo e de magistratura; c) processos rapidos e oraes; d) acabar com as accumulações remuneradas; e) ampliar o "habeas-corpus"; f) acabar com o estado de sitio ou, ao menos, abrandar os seus effeitos; g) com o suffragio universal estender o voto á mulheres; $h$ ) reorganizar a defesa nacional em novás bases, modificando o exercito; i) adoptar o principio da irresponsabilidade do presidente durante o mandato, responsabilizando-o 1 anno 
depois de deixar elle o cargo, ficando bem claro que o presidente durante 3 annos depois de deixar o logar não poderá occupar nenhum outro de eleição.

\section{CONFERENCIAS PUBLICAS}

Para conseguir-se este escopo, este programma reformista, seria necessario, repito, educar o povo.

Para isso, um grupo de patriotas, de homens de boa vontade, de convioções, honestos, puros e desinteressados, tomaria a seu cargo educar o povo por meio de confèrencias publicas.

Estas deverão versar sobre historia patria, moral, religião, civismo, geographia, politica, hygiene, historia geral, etc.

Nunca perder de vista comtudo o ponto primordial: augmentar entre os brasileiros o amor e o conhecimento do Brasil; procurar assimilar o extrangeiro; jesenvolver o amor pela liberdade, mostrando as vantagens da democracia; salientar que o Brasil deve constituir um grande toldo, incutindo em todos o horror á desagregação nacional

E' o que penso sobre a nossa situação politica.

Os homens de bem devem unir-se para levar avante esta grande cruzada: - fazer do Brasil o paiz mais livre, democratico e culto da America!

Braz de Sousa Arruda. 